\title{
Pour une stylistique du « taxème » dans le débat politique télévisé : Analyse de quelques réseaux interactionnels signifiants
}

\section{Laurent Rouveyrol}

\section{(2) OpenEdition \\ Journals}

Édition électronique

URL : http://journals.openedition.org/asp/2335

DOI : 10.4000/asp.2335

ISBN : 978-2-8218-0380-0

ISSN : 2108-6354

\section{Éditeur}

Groupe d'étude et de recherche en anglais de spécialité

\section{Édition imprimée}

Date de publication : 1 décembre 1999

Pagination : $99-119$

ISSN : 1246-8185

Référence électronique

Laurent Rouveyrol, «Pour une stylistique du « taxème » dans le débat politique télévisé : Analyse de quelques réseaux interactionnels signifiants », ASp [En ligne], 23-26 | 1999, mis en ligne le 16 mars 2011, consulté le 19 avril 2019. URL : http://journals.openedition.org/asp/2335 ; DOI : 10.4000/ asp. 2335

Ce document a été généré automatiquement le 19 avril 2019

Tous droits réservés 


\title{
Pour une stylistique du " taxème » dans le débat politique télévisé: Analyse de quelques réseaux interactionnels signifiants
}

\author{
Laurent Rouveyrol
}

\section{Introduction}

1 Dans ${ }^{1}$ l'approche développée par Kerbrat-Orecchioni (1992: passim), le méta-terme de "taxème" ( $\mathrm{du}$ grec taxis: place) renvoie à des phénomènes langagiers plus que linguistiques, très hétérogènes et de nature essentiellement sémiotique. Ils sont l'indication mais aussi la réalisation « rapports de place » définissant dans une interaction les relations inter-personnelles sur un axe vertical. Comment les divers participants d'un débat parviennent-ils à se placer les uns au dessus des autres? Quelles stratégies locales peuvent-ils mettre en place pour satisfaire ce désir? Telles sont les questions que nous allons devoir nous poser par rapport à notre corpus. Celui-ci est constitué d'extraits de deux émissions de télévision diffusées sur la BBC ayant pour titre: "Question Time». Quatre personnalités civiles sont invitées sur le plateau pour débattre de l'actualité à partir de questions émanant directement du public qui contrairement aux débats classiques peut intervenir, réagir, prendre à parti... Les invités sont souvent des politiciens d'idéologies divergentes et des journalistes, universitaires, spécialistes de tel ou tel problème.

2 Nous évoluons donc dans un territoire qui est ontologiquement pragmatique et interactionnel : nous considérons d'un point de vue hiérarchique les différents locuteurs. Il va également de soi qu'une perspective dynamique est à adopter, nous venons de parler de stratégies locales, ce qui implique qu'un analyste ne saurait considérer qu'un locuteur donné domine en tout et pour tout une interaction donnée, les différents participants 
doivent constamment négocier leur situation sur l'axe taxémique et sur plusieurs fronts en même temps, lâchant du lest ici, reprenant l'avantage là....

3 Nous allons donc partir des extensions du concept de taxème telles qu'elles sont envisagées par Kerbrat-Orecchioni (ibid.) dans le cadre général de l'interaction verbale pour ensuite poser la question de savoir s'il n'existe pas de fait de discours taxémiques, spécifiques à l'interaction télévisée.

\section{Au niveau de l'interaction interne}

4 Nous considérons ${ }^{2}$ ici l'interaction télévisée comme une interaction verbale anodine, dont la caméra serait témoin et qui servirait à la retransmettre. Nous cherchons donc les instances discursives permettant aux participants à l'émission de se positionner les uns par rapport aux autres sur un axe vertical.

Kerbrat-Orecchioni exprime d'entrée de jeu le caractère hétérogène du fait taxémique et distingue plusieurs axes de recherche. Certains paramètres doivent être pris en compte et sont indispensables pour identifier des faits pertinents dans le discours : le genre, il s'agit d'une interaction médiatisée régie par des règles particulières et la nature des participants.

6 L'émission considérée fonctionne sur un mode égalitaire, qui se manifeste à plusieurs niveaux: tout d'abord les participants membres du panel sont autour d'une table et interviennent lorsque le "modérateur ", "hyper-locuteur ", le journaliste maître de la rencontre le leur demande. L'interaction est déjà particularisée par ce protocole ; on peut presque penser que nous avons affaire à un entretien croisé, plus qu'à une véritable interaction. Bien entendu, des tentatives d'intervention sauvages sont aussi à redouter et nous tenons là une extension qui fonctionne au niveau de la structure interactionnelle.

7 Le politicien, universitaire, journaliste candide, sont donc a priori sur le même plan. Nous travaillerons à partir de deux émissions. La première, ayant eu lieu pendant la campagne législative qui a vu la victoire de Tony Blair, met en scène un ministre conservateur, un membre travailliste du cabinet fantôme, une baronne démocrate libérale et un rédacteur en chef adjoint du Spectator. L'autre émission, plus ancienne, date de 1992 et présente Kenneth Baker, sans portefeuille de ministre, conservateur, un député européen travailliste, un haut fonctionnaire et un enseignant de LSE Le cinquième élément participant à part entière au débat est le public, qui pose les questions et initie les séquences thématiques ${ }^{3}$.

$8 \mathrm{Au}$ cours de l'émission, le public est invité à réagir aux paroles qui viennent d'être prononcées, sans que cela ait été réglé à l'avance et on assiste parfois à des échanges très secs entre par exemple un membre du public et un ministre, Michael Portillo, le débat porte sur les chiffres du chômage en Grande-Bretagne et ceux d'autres pays européens :

(1) Woman: I'd like to ask Michael Portillo/ your figure for people in work in Britain/

M.P.: Yes?

Woman: Is that full time work or part time work?

M.P.: It's, it is both

Woman: $\boldsymbol{A h}$ cos I know we are the highest in the E.E.C for part time workers

so I don't see that's comparable

M.P.: But that is because we do surveys of part time workers

Woman: Hum hum 
M.P.: And ninety percent of part time workers work part time because that's what they want to do (moans and groans from audience)

Woman: Ah I'd like to see how that that survey that you you know the actual questionnaire

M.P.: By all means if you let me have your address I'll let you, I'll let you have the survey

(2) A.M.: Can I can I..

DD: No I just want to bring some more people in// Th- the man in the third row here

1 Les personnes publiques, membres du panel vont donc devoir tenter d'agir sur ce cadre apparemment égalitaire pour constituer des rapports de place spécifiques à chacun d'eux au niveau local. Si on analyse l'interaction dans sa globalité en considérant chaque locuteur on doit pouvoir établir le « score taxémique » qu'il réalise.

A priori on pense maintenant savoir où chercher et quoi regarder, les choix lexicaux, syntaxiques réalisés par les différents locuteurs ainsi que ceux qui concernent directement la structure de l'interaction et la façon de la gérer. Nous parlerons essentiellement de taxèmes verbaux mais il est clair que le taxème peut revêtir également des extensions non verbales ou para-verbales : la prosodie ou les données vocales sont autant d'indices à ce niveau. Ces dernières ne font pas à proprement parler partie de notre étude, mais il est clair que le débit peut revêtir un aspect taxémique: d'après Kerbrat-Orecchioni (1992: 81) toujours, quelqu'un qui parle lentement se présente comme sûr de lui et ne craint pas d'être coupé, contrairement à quelqu'un qui a un débit rapide.

13 L'identification d'un débit lent ou rapide doit se faire avec la plus grande vigilance. Des recherches récentes ${ }^{4}$ montrent que les femmes ont un débit qui peut être quadruple de celui des hommes dans une même interaction. Cela se vérifie ici : A. McElroy est très difficile à transcrire, si cela peut constituer une évaluation objective et sérieuse du débit.

Pour ce qui est des extensions verbales du phénomène taxémique, il nous faut adopter une perspective qui accepte la prise en compte de la dynamique interactionnelle aussi bien que celle de l'hétérogénéité des marques, nous voyons ici encore pourquoi une approche stylistique dont l'objet est de pouvoir constituer des réseaux finalisés à partir d'éléments discrets est indispensable. Nous suivons en cela la perspective développée, par M. Petit (1997) qui pourrait s'exprimer comme ceci : en tronquant Molinié (1993 : 1, 2 cité par Petit) :

L'objet majeur et éminent de la stylistique [...] c'est le caractère spécifique [...] de la praxis langagière telle qu'elle est concrètement développée, réalisée, à travers un régime bien particulier de fonctionnement du langage [...].

Pour appréhender cette " praxis langagière spécifique ", nous disposons du concept de «cadre interactif » développé par Vion (1997) et l'équipe de l'AFL. Ce cadre est formalisé 
par le modèle à cinq places qui consacre le réseau interactionnel dans son ensemble ${ }^{5}$ (voir figure 1).

Figure 1

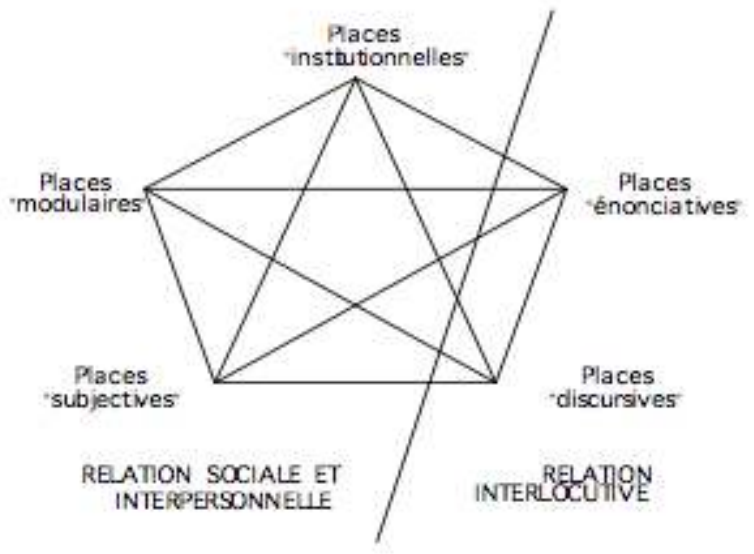

Nous avons parlé précédemment de rapports de place négociés constamment au fil de l'interaction. Ce modèle permet de fédérer cinq places, gérées en même temps par un locuteur donné et de caractériser les rapports, il nous autorise à prendre en compte tant les phénomènes liés à la relation sociale tissée entre les participants que des réalisations linguistiquement marquées de taxèmes. Les rapports sont nécessairement binaires, symétriques ou dissymétriques.

- Les places institutionnelles peuvent servir à définir un type d'interaction, ici nous sommes dans un débat télévisé, le rapport institutionnel sera «invité à un débat/autre invité ou membre du public».

- Les places modulaires correspondent à des moments interactionnels subordonnés au type dominant. Nous envisageons ici les modules initiés par les participants : polémique...

- Les places subjectives permettent d'étudier en détail les positionnements hiérarchiques inter-personnels. C'est à ce niveau que se trouvent les taxèmes les participants évolueront à leur gré créant des rapports en fonction de l'image de sujet social qu'ils souhaitent se construire : Expert/non expert...

- Les places discursives renvoient aux interventions réalisées par les co-locuteurs, en tant qu'agencement de mouvements discursifs cohérents, d'après la définition de Moeschler. Nous évoluons ici au niveau de tâches cognitivo-discursives, les rapports seront : Narrateur/ narrataire ; consultant/consulté...

- Les places énonciatives concernent les énoncés analysés isolément. Nous pourrons faire intervenir le concept de mise en scène énonciative, qui analyse comment un locuteur distribue les voies dans son propre discours, la façon dont il se met en scène. Parle-t-il seul ? Est-il effacé, très présent dans son discours ${ }^{6}$ ? L'emploi des pronoms personnels ainsi que les choix lexicaux, termes d'adresse, noms de titre seront des indications précieuses pour déterminer l'interaction qu'un locuteur donné souhaite construire.

17 Notre cheminement consiste donc à adopter un point de vue à partir des places subjectives pour considérer les connexions réalisées avec les autres places, autrement dit pour identifier les traces linguistiques des réalisations taxémiques. La tâche est rendue ardue par le caractère hétérogène des marques sur lesquelles il est difficile d'anticiper. De 
même, l'ambiguïté inhérente à certains actes communicationnels demande une analyse précise où le contexte joue un rôle déterminant.

\subsection{Le niveau discursif}

18 Il semble a priori possible de proposer quelques identifications de taxèmes au niveau discursif, ou macro-discursif. Il est clair que quelqu'un qui monopolise la parole par exemple et en produit nécessairement davantage a tendance à se placer au dessus de ses co-locuteurs. Il s'agit là d'une évaluation globale devant être nuancée. Si Michael Portillo dans le corpus prononce 2613 occurrences, contre 1075 pour A. McElroy, 1435 pour S. Williams et 981 pour A. Smith, il ne donne pas l'impression de dominer l'émission de bout en bout au contraire. En tant que ministre à la veille de l'élection législative, il doit s'expliquer sur son bilan et donner les raisons des choix faits. Le contexte socio-politique du moment fait que sa parole est sollicitée davantage. Cependant, il faut bien reconnaître que devoir expliquer, au sens de justifier, c'est déjà être cantonné à une position basse. L'extrait proposé plus haut en est un exemple, on en trouve beaucoup d'autres, qui sont autant de réactions vives de désapprobation, parfois très violentes.

\subsubsection{Variété et style}

Kerbrat-Orecchioni (1992: 83) mentionne le fait que l'utilisation de «technolectes » peut être taxémique pour un locuteur donné. Il est évident que le jargon du spécialiste confère au locuteur une place de spécialiste qui condamne donc les co-locuteurs à une certaine immanence. S'il est possible d'étendre le concept de technolecte jusqu'à lui faire couvrir la notion de "langue du technocrate", nous trouvons plusieurs exemples de ce type de choix dans le corpus. $\mathrm{K}$. Baker répond à une question concernant la fermeture de quelques puits de charbon:

(3) K.B.: Well, it's, it's not, it's not a political closure programme, it's a political keeping open programme. And the problem the British coal had to address last October, was that the demand for coal was falling and falling rapidly, and they were producing too much coal. That problem, is no different today. It's exactly the same problem, there's a limited market for coal, ah, the actual coal used by the power generators in our country is about sixty five to seventy million tons a year, we have forty five million tons of mined coal piled up in heaps at generating stations and at pit heads. More than half a year's supply! And that was the problem that Michael Heseltine had to address then, and probably has to address today, and he's certainly changed his view, yes, we listened because there was a great deal of protest. But the problem is the same, and when you talk of the balance of energy policy, that's exactly what we have, because you have to balance between coal, which we own, and produce, oil, which we own and produce, gas, which we own and produce, nuclear power stations which we own and generate electricity, and a small amount imported from France, and that amount is going to go down, and part of the deal, is that we'll be able to sell some of our spare electricity at certain times of the year to the French. And so, what he's had to do, is to face this very difficult reality, and I think that in fact it's a sensible package, hum, there's first firm contracts for a hundred and sixty million tons for the next five years, secondly, there's a price subsidy, which we as tax payers, you as tax payers will all have to pay in fact, ah, and that is a subsidy that's going to be paid to those pits that remain open, in order to help them sell their coal. And the production price of 
British coal is about a third more than delivered coal at Thames wharves, because we have very deep mines, and narrow seams, and so we're saying we're prepared to bridge this gap and the subsidy to keep 12 more pits going. et image de technocrate. On peut citer en contrepoint l'extrait suivant qui démontre qu'une autre attitude est possible, Pauline Green à propos des sommes allouées à l'exURSS déclare :

(4) P.G.: But, the problems of Russia are vast, one of the things that we've been doing is putting into Russia, a great deal of money in terms of economic aid [...]

Elle pourrait citer le chiffre qu'elle connaît certainement, le contexte s'y prête, pourtant elle ne le fait pas. Sans doute ne souhaite-t-elle pas jouer sur un registre Expert/non expert. Le même locuteur dira d'ailleurs un peu plus loin à propos des actes de violence perpétrés dans les écoles anglaises :

(5) P.G.: Of course you can always point to some of those statistics, but you've also got to look at the positives, about what's happening in our schools and we have some very fine young people, who we must actually engender that confidence that we have in them.

\subsubsection{Le glissement thématique}

S'approprier l'interaction est sans conteste une marque de supériorité interlocutive ; cela est d'autant plus vrai ici que les séquences thématiques sont imposées aux participants. CEuvrer pour changer le thème c'est marquer clairement une volonté de tirer l'avantage à soi. Nous en avons un vibrant exemple ci-dessous. La question porte sur le fait que le journal The Sun ne soutient plus les conservateurs :

(6) S.W.: what worries me is that some of the/ crucial decisions about multimedia ownership are going to be made in the next Parliament// Among other things they're going to be concerned with the whole issue of digitalisation of the mass media/ and during the Broadcasting Bill which was discussed in Parliament two years ago/ on the issue of multimedia ownership/ we in the Liberal Democrats found Labour, to be honest, somewhat weak/ in comparison to what we expected which was a strong line against/ powerful ownership by a limited number of multimedia er major figures// So I'm worried// I wouldn't suggest that's the reason The Sun has changed but I'm perfectly certain that there are considerations which must be in the mind of Mr Murdoch and others/ about their future position in a world where the multimedia are becoming more and more globalised.

Il est difficile de savoir quelle est la question posée si on ne la connait pas. Il pourrait s'agir de multimédia, de débat parlementaire concernant la presse... Il faut attendre la fin de l'intervention de $\mathrm{S}$. Williams pour avoir le nom du journal qui rattache l'intervention à la question. L'intention du locuteur ici est de parler d'autre chose et cela est explicitement dit : «I wouldn't suggest that's the reason The Sun has changed ». Il faut admettre que S.W. n'a pas répondu à la question et qu'elle le sait. La question est prétexte et permet d'ouvrir sur autre chose. 


\subsubsection{I'll tell you a story...} discursive est sans conteste le fait de pouvoir forcer au mutisme les co-participants en choisissant un genre discursif qui l'implique directement. Si vous racontez une histoire, anecdote, vous devenez conteur, narrateur et à partir de là les co-locuteurs qui sont à côté de vous sont réduits au rang de narrataire et sont privés de la parole. Kenneth Baker en donne un exemple :

(7) K.B.: [...] Now I saw this actually operating in a very rundown inner city school in the Bronx in America when I was Education Secretary, and it was a much more difficult school than anywhere that I ever saw in Britain. The children were frisked as they went into the playground for drugs or for weapons and there was a wonderful head, headmaster who'd saved the school and pulled it up, and it was rather old fashioned first he insisted that all the children turn up on time, this is inner city, all the children are either black or Hispanic. Turn up on time, don't answer the teacher back in class, don't fight in the corridors, pull up your socks, look tidy, all those sorts of things and you instil an ethos in the place. [...]

Le mouvement discursif est initié par un «now » embrayeur. K.B. raconte une anecdote au cours de laquelle il officie en tant que maître absolu de son discours, il distribue la parole et convoque un énonciateur fictif qu'il intègre à son discours.

\subsubsection{Les résultats de l'argumentation}

Dans une interaction classique, il est facile d'identifier les instants où un locuteur se hisse au dessus d'un autre parce qu'il parvient au moyen d'une argumentation adaptée et efficace à le convaincre du bien-fondé voire du « mieux fondé » de ses opinions.

Ici, il est difficile de penser qu'un conservateur va rallier à son opinion un travailliste, ou inversement. Il est donc ardu d'évaluer une argumentation en termes taxémiques. Le public présent sur le plateau gratifie pourtant certaines interventions d'applaudissements chaleureux. Le locuteur ainsi salué par l'enthousiasme se trouve donc porté en triomphe un court instant.

Nous sommes ici dans un domaine très subjectif, et l'analyste a bien du mal à déterminer ce qui cause l'adhésion du public d'une façon aussi unanime. Il n'est pas rare de voir que deux interventions successives exprimant une divergence d'opinions puissent être applaudies l'une après l'autre :

(8) P.G.: Now, I believe frankly that the school is one of the areas in which sex education is dealt with, as well as at home in the environment at home where most young people learn about a relationship and the need for good solid relationships, but school is another environment particularly where we deal with sex education as is a clinic or whatever, there are different parts of our community which deal with these issues. And if it's right, that within that environment and in that discussion within a school, the provision of a condom to young people over sixteen, is of assistance in dealing with the very difficult adolescent behaviour which they're confronted with at all times, I personally don't find that a difficulty, huh, and I think it part of the sensitive education that they get in terms of sexual education, within a school or and within their home and obviously, with the consent and 
knowledge of parents. Huh, and obviously governors and parent-teachers associations will also have been involved in this decision-making, I don't see that it is anyway harmful to be looking at the provision of condoms for that post sixteen age group within their general sex education.

Public: (Applaudissements)

J.: David Starkey:

D.S.: I think there are two things, the general tendency is fairly well established sociologically I think that the typical teenage mum is a sort of girl who probably won't use contraceptives anyway and maybe you could encourage it. It seems to me to be a very faint hope. That's point one. Point two : I think there are immense problems in trying to manage coeducational schools with the kind of extra-subtle pressures that we have at the moment. I talk in schools a great deal, I lecture to them a lot, and one of the things that strikes me is generally speaking particularly for girls how much better single sex schools are. I'm being deeply old-fashioned about this, they can actually concentrate on learning without this enormous network of surrogate mock-passionate romances, far too early in their lives, (rires) I'm being old-fashioned, I'm being silly, but I actually believe it.

Public: (Applaudissements). dans le cadre du débat politique, certains énoncés sont dissociables d'autres par le fait qu'ils réalisent un positionnement taxémique.

\subsubsection{Les taxèmes explicites : à la recherche de la légitimité discursive}

31

$$
\begin{aligned}
& \text { individus les uns des autres et de les placer plus ou moins haut sur l'axe taxémique en } \\
& \text { fonction de la valeur sociale attribuée à ces titres. Existe-t-il dans notre corpus des } \\
& \text { locuteurs qui rappellent les titres dont ils jouissent ou ont joui pour se placer au dessus de } \\
& \text { leurs co-participants. } \\
& 32 \text { En fait, sur les deux émissions étudiées, une ne comporte aucun énoncé de ce type. La } \\
& \text { seconde en revanche en comporte certains, émanant à la fois d'un membre du panel } \\
& \text { (toujours le même) et chose impensable de membres du public. } \\
& \text { (9) K.B.: [...] the other terrorist incidents that I remember I had to deal with } \\
& \text { when I was Home Secretary. }
\end{aligned}
$$

Le début de l'exemple (7) en est un autre exemple :

(7) K.B ;: Now I saw this actually operating in a very rundown inner city school in the Bronx in America when I was Education Secretary.

Chose étrange, les membres du public certainement en quête de légitimité discursive ${ }^{7}$ donnent parfois dans le genre ainsi en réaction à certaines interventions de membres du panel, on peut parfois entendre : 
(10) P10: Yes, I work as an educational psychologist in a London borough $\mathrm{J}$ : No but tell us from your experience, why children attack their teachers?

Certains actes de langage peuvent avoir une valeur taxémique. Kerbrat-Orecchioni (1992: concepts mis au point par Brown et Levinson à partir des travaux de Goffman, ces actes prennent le nom de «face threatening acts » (FTAs) et l'on peut distinguer quatre schémas principaux qui seront envisagés simultanément.

(1a) L1 se met en position haute par rapport à L2 lorsqu'il accomplit un acte potentiellement menaçant pour l'une ou l'autre des faces de L2,

- Face négative : ordre, requête, interdiction, autorisation suggestion, conseil, etc., c'est-à-dire toute la série des «directifs » qui constituent pour L2 des espèces d'incursions territoriales ; 
41 A priori, ce genre d'actes de langage semble difficile à trouver du moins si l'on considère le problème en termes d'action. Si en revanche, on essaie de considérer les actes de ce type qui portent sur l'énonciation, le dire, alors on en trouve quelques-uns. Cependant, ces énoncés sont à cheval entre le cas étudié et celui qui sera envisagé tout de suite après. Tout d'abord, ils sont indirects puisque non explicites, en vertu de la loi de liberté d'opinion, il n'est pas concevable d'entendre « you can't say that ». Un énoncé comme « I reject that view » (extrait 11) a certainement la valeur de « you can't say that » dans la bouche du locuteur.

(1b) - Face positive : critique, invective, moquerie, railleries, désaccords en tous genres (objection, contestation, réfutation, refus d'obtempérer, blâme et reproche, injure ou insulte, provocation et défi), c'est-à-dire l'ensemble des comportements vexatoires, qui sont susceptibles d'infliger à L2 une blessure narcissique plus ou moins grave.

Nous sommes là au cœur du débat et bien entendu ces actes sont les plus nombreux. Je dirais même qu'à la limite ces actes sont le centre d'intérêt essentiel de l'émission. Le fait d'inviter des politiciens d'opinions divergentes est déjà une façon d'initier ce genre de comportement plus ou moins agressif qui fait partie du jeu.

Bien des exemples déjà cités peuvent être réinvestis ici, notamment concernant la réfutation, pendent obligatoire de l'acte d'argumentation déjà envisagé.

(14) S.W.: Is my description wrong Michael?// Am I wrong about what I

said what it says?

M.P.: This isn't a sued book

S.W.: I'm sorry I've just gotta put this one question

M.P.: Yes you are wrong Shirley because the important

S.W.: Why am I wrong?// What's the other items in it?

M.P.: The/ all the items that they wish to vote on in the future

S.W.: Oh at some future date $\mathrm{OK}$

M.P.: Anyth- yes because what you say

S.W.: Like (rest of comment unheard)

M.P.: If you join the Social Chapter Shirley what you say is we no longer control our own social policy it will be whatever the majority vote in Europe is

(someone interjects)

Dans l'extrait ci-dessus, les deux protagonistes s'affrontent sur leurs dires respectifs : « my description" renvoie à une intervention préalable. On remarque de nombreuses occurrences du verbe «say» qui montrent que les locuteurs sont au corps à corps sur le terrain. Ce que dit L1 n'est pas vrai, dans le genre, on peut aussi citer :

(15) M.P.: That's not true Shirley, that isn't true.

Les lois de bienséance empêchent a priori de rencontrer des insultes ou injures ou énoncés attaquant directement la personne parlante. Pourtant ces actes sont présents dans le corpus.

Dans la terminologie de Perelman /Olbrechts-Tyteca (1970: 150), il s'agit d'une argumentation ad personam ce qui correspond à une "attaque contre la personne de l'adversaire et qui vise essentiellement à disqualifier ce dernier »

(16) D.S.: Certainly, the only people who have ever successfully ruled Russia have been those who've killed and the really successfully rulers have killed 
millions. It's true! (rires)

J: Pauline Green:

P.G.: It's terrifying, now what a terrifying, terrifying..... I can't even begin to

think low in that way! \

D.S.: or think

P.G.: the problems, the problems (Rires) of Russia, (Applaudissements),

$\mathrm{J}$ : That wasn't very chivalrous!

D.S.: It's not chivalrous but it's true !

P.G.: the problems hah, that sort of bullying is quite out of order I think and

I'm taking absolutely no notice of it ! (applaudissements) [...]

Cette attaque est très virulente et relativement gratuite. On en trouve d'autres légèrement moins agressives :

(17) K.B.: [...] if you think the problem of mining is a result of privatisation, you don't understand the history of the coal mining industry

(18) K.B.: [...] that is not the object and I don't think you have an understanding of what it's about !

(2a) L1 est mis ou se met en position basse lorsqu'il subit un F.T.A ou lorsqu'il s'inflige à lui-même un acte menaçant pour l'une ou l'autre de ses propres faces :

- négative: promesse (laquelle vous engage donc menace votre propre territoire) et autres promissifs searliens

Aussi incroyable que cela puisse paraître, certaines interventions s'apparentent à des promesses. Les exemples suivants s'adressent à des membres du public. L'extrait 1 en comporte une :

(1) Woman: Ah I'd like to see how that that survey that you you know the actual questionnaire

M.P.: By all means if you let me have your address I'll let you I'll let you have the survey

(2b) - positive, remerciement, excuse, aveu, rétraction, (l'attitude consistant à retourner sa veste) auto-critique, auto-dépréciation...

De tels exemples sont très rares et pas toujours convaincants en fait. Nous avons trouvé une occurrence du phénomène, Michael Portillo, ministre conservateur bat légèrement sa coulpe ou celle du gouvernement (d'une façon très indirecte) quand il déclare à propos de l'attribution des pensions militaires aux vétérans du Golfe :

(19) M.P .: Er y- Andrew I I mentioned that as a matter of fact I said that if there were problems with the way the War Pensions Agency was dealing with them/ then I did think that should be speeded up but obviously they have to be sure that the person qualifies for the war pension/ that is perfectly reasonable you can't just hand out public money

On voit quand même que le «but » suivant « should » minimise la portée de l'acte qui se termine sur un tout autre mode.

Kerbrat-Orecchioni s'empresse d'ajouter que la tâche d'attribution de valeur taxémique à un acte de langage est grandement compliquée par l'existence des A.L indirects (1992: 96), question valant pour une requête, énoncé déclaratif valant pour une question. Dans l'ensemble d'extraits déjà proposés, il est possible de vérifier cette hypothèse. 

qui peut être plus ou moins brutale (nous l'avons vérifié avec les extraits 1617 18). Cette valeur est donc une question de degré.

Kerbrat-Orecchioni (1992 : 98) remarque que :

la force taxémique d'un acte de langage réalisé, dépend à la fois de sa formulation particulière et de sa nature intrinsèque propre : les A.L se distribuent selon ce que l'on peut appeler une «échelle taxémique » on aura par exemple ordonnés du plus au moins menaçant : ordre reproche, conseil, assentiment.

D'après ce que nous venons d'analyser, on peut subjectivement proposer un ordre graduel spécifique au corpus :

Attaque ad personam/ad hominem/intrusion, réfutation directe, réfutation à retardement....

On s'aperçoit également que cet axe proposé va du micro au macro et du dialogique au monologique. Il est également évident que cela n'est qu'une tendance à nuancer au cas par cas.

\subsubsection{Les actes méta-discursifs}

Cette catégorie, non envisagée par Kerbrat-Orecchioni dont l'objet est de mettre au point un cadre général, est très présente dans notre corpus. Quoi de plus taxémique pour un locuteur que de s'approprier le rôle du meneur de jeu en essayant de caractériser d'un point de vue méta-interactionnel les interventions des autres participants :

(20) S.W.: Michael's going a lot into this answer/ he's going a lot into this answer (laughter)

On trouve aussi des interventions concernant le méta-communicationnel :

(21) M.P.: No in the meantime/ Shirley Shirley you're not listening to what I'm saying they are

SW: I'm listening very carefully to what you're saying

on a déjà vu par exemple :

(16) P.G.: that sort of bullying is quite out of order I think and I'm taking absolutely no notice of it ! (applaudissements) [...]

Nous venons d'envisager un long catalogue de faits ayant cours au niveau interne de l'interaction, s'arrêter là c'est rater une dimension intrinsèque du débat télévisé. En effet, l'interaction est double, non seulement les acteurs parlent entre eux, mais ils s'adressent aussi au téléspectateur devant son poste de télévision. Cela pour Viallon définit le niveau interactionnel externe.

\section{L'Interaction au niveau externe, vers une synthèse possible}

Certains énoncés peuvent être interprétés en termes taxémiques par rapport à ce niveau de l'interaction. On a identifié des faits qui permettaient aux différents locuteurs de se mettre au dessus des autres participants, peut-être peut-on en trouver qui permettent de se placer absolument au dessus de tous les allocutaires potentiels. Nous essayons 
d'identifier maintenant les taxèmes relevant du plan interactionnel spécifique au discours médiatisé.

On peut en effet se poser la question de savoir si ce niveau d'interaction ne peut pas modifier certaines interprétations déjà avancées. Tous les linguistes travaillant sur l'interaction s'accordent à reconnaître que le « tu » exerce une pression sur le « je », cela est indéniable et nous espérons l'avoir montré; d'autres vont plus loin en considérant que plus le nombre de spectateurs est grand, plus les contraintes se font sentir à la source de l'énonciation. Les risques sont grands pour un locuteur à la télévision, surtout si ce dernier a des ambitions perlocutoires affichées de type électoral... Il est des règles implicites, éthico-culturelles que l'on ne peut ignorer.

61 Le taxème relève d'une double problématique. Un locuteur se placera par un procédé quelconque au-dessus d'un co-locuteur, mais quand en est-il de l'allocutaire potentiel que représente le téléspectateur? Un indice d'évaluation perlocutoire est par exemple l'enthousiasme représenté par les applaudissements.

62 Ainsi cela affecte le fonctionnement général des A.L. Tout d'abord, l'idée de se mettre au dessus des autres est en soi mal perçue dans les sociétés occidentales, cela peut être lourd en termes de retour d'image : les allocutaires théoriques de cette parole nécessairement bi-adressée, renvoient aux locuteurs une réaction émotionnelle directement déterminée par leur attitude. Chaque A.L est donc investi d'un effet boomerang incontournable.

L'énoncé taxémique ayant cours dans l'interaction télévisée doit donc être envisagé à la croisée des deux problématiques : l'une étant énonciative et l'autre pragmatique, puisque l'angle d'approche est celui de l'allocutaire.

Un énoncé très agressif, un "coup bas » pourra avoir du point de vue du locuteur une valeur taxémique, mais à ce moment-là le téléspectateur peut considérer qu'il n'est pas digne de figurer dans le cadre.

Si l'exemple 6 place S.W au dessus des autres participants parce qu'elle s'approprie l'espace d'un instant l'interaction, il est clair qu'elle risquerait gros en termes d'image et de considération du public à continuer dans cette voie. L'évitement des questions est dépréciatif ipso facto, si cela s'avère être un fait récurrent.

66 L'existence de ces méta-règles tacites explique peut-être pourquoi nous ne trouvons que deux énoncés relevant du taxème explicite. Il est un fait connu que se mettre en avant et dire «I» à tout bout de champ peut être jugé agaçant. «I» est à la fois locuteur et délocuté, l'implication en cas de fréquence politiquement incorrecte est que seul luimême est digne d'intérêt pour le locuteur considéré.

67 Il est temps maintenant de se poser des interrogations d'ordre formel. Le nombre d'énoncés relevé n'autorise certes pas une description exhaustive définitive. Il paraît tout de même intéressant d'envisager dans le cadre d'une première étape, un élément apparemment très important au niveau de la coloration des énoncés taxémiques: les marques déictiques.

\subsection{Le jeu intersubjectif, quelques remarques formelles}

L'utilisation des pronoms permet au locuteur d'instaurer un jeu intersubjectif particulier. Seront considérés ici deux cas de figure : ce jeu peut être envisagé en fonction de l'adresse réalisée vers les autres participants mais aussi d'un point de vue plus purement énonciatif la façon dont les divers locuteurs se mettent eux même en scène. 


\subsubsection{We}

69 Si l'on regarde la typologie des mises en scène énonciatives développées par Vion (1997), on s'aperçoit que l'utilisation très courante du pronom « we » relève de ce qu'il appelle le parallélisme énonciatif «la position énonciative du locuteur converge avec d'autres voix ».

70 Nous avions dans une précédente communication proposé de distinguer une mise en scène du porte-parole taxémique (19) d'une mise en scène non taxémique (20).

(22) K.B.: and at the end of it/ we hope/ some of those pits will be economic

(23) P.G.: that's why $\backslash$. .. $\backslash$ we're in this position with coal now

71 Le «we» de l'exemple 19 renvoie au [locuteur + le gouvernement], alors que le «we» présent dans (20) a pour référent [le locuteur + le peuple britannique].

72 L'analyse peut être nuancée maintenant que l'on considère l'interaction externe: l'énoncé (20) peut être évalué aussi en termes taxémiques puisque se poser comme représentant du peuple c'est aussi se placer à une certaine graduation de l'échelle taxémique. C'est jouer sur la structure externe de l'interaction puisque se trouvent représentés les allocutaires théoriques de l'interaction, ceci constitue un clin d'œil.

\subsubsection{You}

L'utilisation du «you» est dangereuse car ce dernier est exclusif du locuteur, il s'ensuit une impression de distance qui peut s'avérer lourde de conséquence pour un politicien. c'est d'ailleurs pour cela certainement que le «you » intervient après le parallélisme énonciatif :

(24) K.B.: we as tax payers/ you as tax payers

Ce pronom accentue l'effet dialogique et interactionnel, ciblant explicitement l'allocutaire visé. Dans l'exemple ci-dessous, le locuteur n'hésite pas à invectiver les allocutaires fictifs avec virulence. On est dans l'opposition exophonique, on s'adresse à des allocutaires absents mais identifiés, pour exprimer un désaccord, voire ici une condamnation.

(25) K.B.: And so the message has to go out that you are unacceptable, you I.R.A terrorists, you are pariahs, you are psychopaths [...]

\subsubsection{You and me}

75 Bien entendu les cas où un locuteur se sert des dires d'un autre souvent absent pour donner plus de poids à sa propre intervention sont nombreux... Il s'agit de cas de parallélisme exophonique :

(26) D.S.:The person who knows Ireland perhaps better than anybody else is Connor Cruse O'Brian and what he says is: "the only way to deal with the I.R.A is internment on both sides of the border for both sets of men of violence." 


\subsubsection{Les énoncés aphoristiques} entre les différents pôles créant ainsi des micro-réseaux particuliers, parfois récurrents. Ainsi pour (3) et (7), il existe une dynamique entre la place discursive et la place énonciative qui ensemble pointent vers un rapport subjectif taxémique. Voir figure 2. 


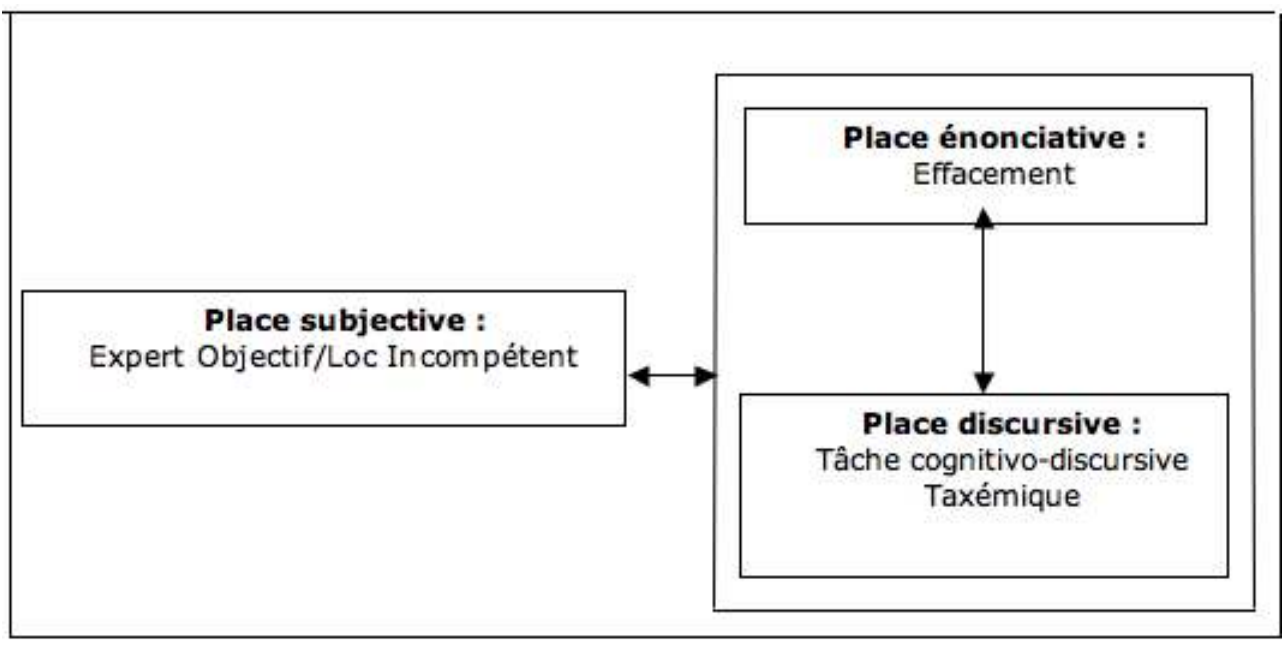

\subsection{Verticalité et horizontalité}

83 On peut relier à ce cas un autre phénomène, qui semble lui aussi destiné à compenser la position réalisée sur l'axe taxémique par la situation sur un autre axe, horizontal celui-là, axe d'intimité. Ainsi on trouve dans le corpus des relationnèmes, des termes d'adresse, qui apparaissent assez incongrus pour un francophone :

(28) P.G.: Until privatisation, Ken, you know very well that Michael Heseltine today has given a two year fixate to privatisation. That's what it's about. famille intervient dans un cadre qui est indirect uniquement : il s'agit de mentionner ce qui a été dit, dans une mise en scène qui est souvent l'opposition diaphonique. Le locuteur joue donc ici sur le niveau de l'interaction externe, il marque qu'il ne s'adresse pas au participant en question et donc que son discours est destiné au téléspectateur. En 
revanche, dans les séquences purement interactionnelles, c'est le prénom qui est utilisé comme en témoigne le reste des exemples. Cela est possible entre membres du panel mais également par rapport au journaliste. Cette hypothèse se vérifie dans les deux interactions.

On est en droit de s'étonner quant à la possibilité d'utiliser le prénom d'un adversaire politique au cours d'un débat télévisé. Qu'en serait-il dans un débat français? En analysant un débat français de la campagne des législatives de 92, nous nous sommes aperçus qu'aucun participant ne se permettait une telle chose. Tout d'abord les amis politiques (de la même famille) ne s'adressent jamais la parole dans l'extrait étudié, ensuite, lorsqu'un politicien parle à un opposant, le nom de famille apparait toujours :

(30) G. Moreau: Lionel Jospin a évoqué l'augmentation des salaires des enseignants

L. Jospin : les chiffres dont parle Monsieur Bayrou...

F. Bayrou : Monsieur Jospin...est-ce que vous m'entendez...

L. Jospin : Bon, écoutez, Monsieur Bayrou: si vous prenez...

A. Waechter : Monsieur Jospin...Monsieur Jospin, simplement le problème c'est que...

F. Bayrou : Madame Moreau, ça fait cinquante ans que vous essayez de faire peur avec ça.

J. Toubon : C'est justement pour ça qu'il faut accorder, Madame Moreau, par les pouvoirs publics, une égalité de choix aux parents entre privé et public.

L. Jospin : Monsieur Bayrou?

F. Bayrou : C'est les deux, Monsieur Jospin!

À en croire ces exemples, le taxème constitue apparemment un fait discursif qui permet de caractériser le débat politique anglais, d'en révéler un caractère à la fois définitoire et spécifique. Kerbrat-Orecchioni montre que la catégorie obtenue en croisant l'axe horizontal et vertical : [hiérarchie + intimité] est en soi contradictoire (1992 : 122). Cela n'exclut pourtant pas que l'on puisse constater une interpénétration des deux axes. Ce qui est sûr en tout cas et malgré le fait selon lequel la télévision développe de plus en plus un vecteur intimiste, c'est que très rarement dans un débat télévisé français réunissant des hommes aux idéologies divergentes, nous ne rencontrerons une telle combinaison ${ }^{8}$.

\section{Conclusion}

Nous avons bien vérifié tout au long de cette étude le caractère hétérogène du phénomène taxémique, qui rend une approche stylistique obligatoire. Ce taxème est à la croisée de faits linguistiques multiples et souvent ambigus, il s'agit d'une dimension essentielle de la communication dans le cadre de l'interaction verbale. Ce phénomène langagier revêt des extensions très diverses dans les fragments de corpus analysés; il s'avère très ardu d'identifier des marques linguistiques spécifiques au phénomène, tant elles relèvent d'ordres divers : interaction, acte de langage, unité discursive monologale etc. La relation entre certaines marques linguistiques récurrentes et le caractère taxémique de l'énoncé n'est de toute façon pas bi-univoque, seule une analyse précise des éléments contextuels au cas par cas permet pour l'instant la localisation de taxèmes. Les quelques fragments relevés autorisent pourtant une certaine caractérisation de ce type d'énoncé dans le cadre ciblé. 

l'interaction télévisée, et ne peut se circonscrire qu'en termes de réseaux. D'autre part, ce fait langagier vertical est empreint d'une dimension horizontale qui le constitue de façon intrinsèque. Autrement dit, l'acte taxémique est très souvent compensé, neutralisé, amoindri d'une façon ou d'une autre.

91 taxémique est une piste permettant à l'analyste de mettre au jour un caractère idiosyncrasique du débat politique anglais, qui se trouve empreint d'un aspect culturel marqué.

\section{BIBLIOGRAPHIE}

Goffman, Erving. 1973. La mise en scène de la vie quotidienne, (tome 2): Les relations en public. Paris : Les éditions de Minuit.

Kerbrat-Orecchioni, Catherine. 1980. L'énonciation, De la subjectivité dans le langage. $2^{\mathrm{e}}$ éd. Paris : Armand Colin.

Kerbrat-Orecchioni, Catherine. 1990. Les interactions verbales (tome 1). Paris : Armand Colin.

Kerbrat-Orecchioni, Catherine. 1992. Les interactions verbales (tome 2). Paris : Armand Colin.

Molinié, Georges. 1997 [1989]; La Stylistique, 4 éd. « Que sais-je ? ».. Paris : Presses Universitaires de France.

Perelman, Chaïm et Lucie Olbrechts-Tyteca. 1988. Traité de l'argumentation, $5^{\mathrm{e}}$ éd. Bruxelles :

Éditions de L'Université de Bruxelles.

Petit, Michel. 1977. « Stylistique(s) contrastive(s) du discours scientifique ». ASp 15-18, 139-156.

Rouveyrol, Laurent. 1998. « Vers une stylistique de l'interaction télévisée : une piste pour l'étude des débats ». Bulletin de la Société de Stylistique Anglaise 19, 9-44.

Viallon, Philippe. 1996. L'analyse du discours de la télévision. «Que sais-je ?», Paris : Presses Universitaires de France.

Vion, Robert. 1992. La communication verbale, Analyse des interaction. Paris : Hachette.

Vion, Robert. 1995. « La gestion pluridimensionnelle du dialogue ». Cahiers de linguistique française, Genève : Université de Genève 17, 179-203.

Vion, Robert. 1997. « La mise en scène énonciative des discours ", Communication au $16^{\mathrm{e}}$ Congrès International des Linguistes, Paris, 20-25 Juillet 1997 (à paraître dans les Actes).

\section{Bibliographie complémentaire}

Adam, Jean-Marie. 1992. Les textes : types et prototypes. Paris : Nathan.

Adam, Jean-Marie. 1997. Le style dans la langue. Paris, Lausanne : Delachaux et Niestlé.

Ducrot, Oswald. 1984. Le dire et le dit. Paris : les Éditions de Minuit. 
Ghiglione, Rodolphe et al. 1989. Je vous ai compris ou l'analyse des discours politiques. Paris : Armand Colin.

Mathis, Gilles.1997. « Stylistique et discours scientifique ». ASp 15-18, 157-183.

Petit, Michel. 1998. « Vers une stylistique du 'hedging', le cas du discours scientifique ». Bulletin de la Société de Stylistique Anglaise 19, 45-79.

Roulet, Eddy et al. 1991 [1985]. L'articulation du discours en français contemporain. $3^{\mathrm{e}}$ éd. Berne : Peter Lang.

Suhamy, Henri. 1994. Stylistique anglaise. Paris : Presses Universitaires de France.

Trognon, Alain et Janine Larrue. 1994. Pragmatique du discours politique. Paris : Armand Colin.

Verschueren, Jeff. 1999. Understanding pragmatics. Londres : Edward Arnold.

\section{NOTES}

1. Texte remanié de la communication réalisée lors du XX $X^{e}$ congrès du GERAS organisé à Cachan.

2. L'expression « interaction interne » est due à Viallon (1996:38).

3. Cette affirmation est à nuancer car le journaliste ne demande pas à un membre du public d'intervenir au hasard pour poser une question au panel, le locuteur est présenté, le journaliste donne son nom et son occupation professionnelle.

4. Comme celles réalisées par C. Maury-Rouan à Aix-en-Provence.

5. Nous nous bornons à rappeler brièvement les outils développés dans Rouveyrol (1998).

6. Bien entendu, nous parlons ici de marques formelles objectives d'investissement énonciatif. Il va de soi pour nous qu'un locuteur donné est toujours présent dans l'énoncé qu'il construit. $\mathrm{Ne}$ serait-ce par le fait que l'énoncé est énoncé et donc endossé subjectivement, même s'il se donne l'apparence de l'objectivité énonciative.

7. Nous sommes parti du principe que la structure de l'émission était égalitaire, en fait on est obligé ici de nuancer cela: les membres du public sont nombreux et donc anonymes, contrairement aux membres du panel, ils ne sont pas présentés en début d'émission, dans la course à la pertinence discursive, certains peuvent ressentir le besoin de se démarquer...

8. Il est tout de même possible de constater de tels faits. Les dernières élections Européennes ont permis aux verts de parler souvent de «Dany» à l'endroit de Daniel Cohn-Bendit. Il est intéressant de remarquer que Dominique Voynet, Ministre de l'environnement en exercice n'hésitait pas à le faire. Nous remercions C.Chanet de nous avoir rappelé ce fait.

\section{RÉSUMÉS}

Cette étude a pour objet d'illustrer et d'analyser les différentes extensions que peuvent prendre dans un corpus de discours politique télévisé anglais les taxèmes ou actes taxémiques, et d'en dégager certaines caractéristiques. Ces énoncés particuliers sont l'indice de positionnements interpersonnels hiérarchisés, subis ou initiés au cours de l'interaction. Nous partirons du postulat que seule une approche stylistique permettant de créer un modèle d'analyse cohérent conçu pour prendre en compte les caractéristiques pragmatiques et situationnelles du genre 
discursif étudié parvient à rendre compte efficacement du phénomène dans sa dynamique hétérogène.

The aim of this paper is to illustrate and analyse the various extensions which may give life to the concept of 'taxeme' in a corpus belonging to the media discourse genre. This specific type of utterance may be defined as semiotic or pragmatic since it indicates the different hierarchical inter-personal positions initiated and undergone during the interaction. It will be argued that only a stylistic approach permits to conceive a coherent analytical model, taking into account all situational and pragmatic parameters in order to give a complete map of this language phenomenon in its full complexity and dynamics.

\section{INDEX}

Keywords : discourse analysis, media discourse, pragmatics, stylistics, utterer-centered approach

Mots-clés : analyse du discours, débat télévisé, énonciation, interaction, pragmatique, stylistique, taxème

\section{AUTEUR}

\section{LAURENT ROUVEYROL}

Laurent Rouveyrol est professeur certifié détaché à l'Université de Provence, Aix-Marseille 1. Il élabore une thèse de linguistique anglaise portant sur l'analyse du débat politique télévisé anglais. Son domaine de recherche linguistique inclut l'analyse des interactions ainsi qu'une approche stylistique et pragmatique du discours oral. laurent.rouveyrol@unice.fr 